\title{
Heterosis Study in Sunflower (Helianthus annuus L.) for Yield Attributing Traits through Line x Tester Matting Design
}

\author{
Shyam Sundar Lakshman', Nihar Ranjan Chakrabarty ${ }^{2}$, Praresh Chandra Kole ${ }^{3}$ \\ ${ }^{1}$ All India Coordinated Research Project-Sunflower, Nimpith-743338, 24 Parganas (S), West Bengal \\ ${ }^{2,3}$ Department of Genetics, Plant Breeding and Crop Physiology, Institute of Agriculture, Palli Siksha \\ Bhavana, Visva-Bharati-731236 \\ *Corresponding Author(Email: lakshmanshyam_ss@yahoo.co.in)
}

How to cite this paper: Lakshman, S.S., Chakrabarty, N.R. and Kole, P.C. (2019). Heterosis Study in Sunflower (Helianthus annuus L.) for Yield Attributing Traits through Line x Tester Matting Design. Grassroots Journal of Natural Resources, 2(4): 13-25. Doi:

https://doi.org/10.33002/nr2581.6853.02042

Received: 03 October 2019

Reviewed: 28 October 2019

Provisionally Accepted: 09 November 2019

Revised: 25 November 2019

Finally Accepted: 12 December 2019

Published: 31 December 2019

Copyright (C) 2019 by author(s) and

The Grassroots Institute.

This work is licensed under the Creative Commons Attribution International License (CC BY 4.0).

http://creativecommons.org/licenses/by/4.0/
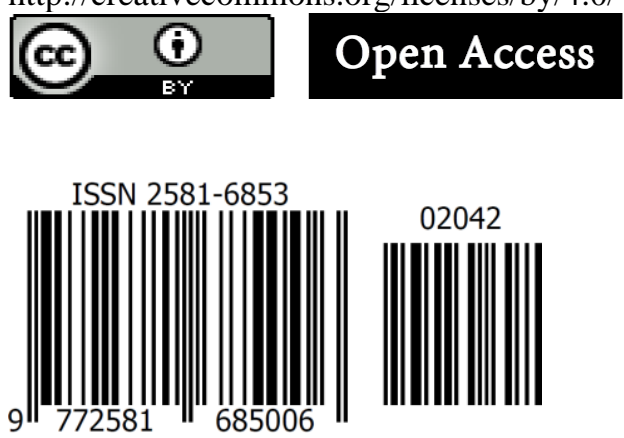

\begin{abstract}
Heterosis is the increase or decrease in vigour of $F_{1}$ over its mid or better parental value. The development of new high yielding and stable sunflower hybrids based on hybridization requires information on the heterotic effects for agronomically important traits in the $F_{1}$ generation. This paper estimates the extent of heterosis for various characters and to isolate promising sunflower hybrids. From the experiment it was revealed that the average heterosis of $8.9 \%$ for days to $50 \%$ flowering, $65.1 \%$ for plant height; $80.3 \%$ for head diameter; $139.8 \%$ for seed yield $(\mathrm{kg} / \mathrm{ha}) ; 107.5 \%$ for number of filled seed/head; $5.9 \%$ for seed filling $\% ; 10.8 \%$ for 100 seed weight, $12.1 \%$ for 100 seed kernel weight, $6.5 \%$ for hull content; $4.7 \%$ for volume weight (g/100 cc); $0.1 \%$ for oil content (\%;) and $140.4 \%$ for oil yield (kg/ha) respectively. In all crosses, seed and oil yield $(\mathrm{kg} / \mathrm{ha})$ traits and other desirable traits, P-2-7-1A, CMS-10 A, P89-1A, EC-601958, R-104, EC-601978, R-138-2, R-630 and R-6D-1 were involved more frequently. Among the 36 sunflower hybrids, for seed yield and oil yield ( $\mathrm{kg} / \mathrm{ha})$, fifteen crosses displayed significant positive sca effects and performance per se, among them the crosses.
\end{abstract}

\section{Keywords}

Sunflower; Heterosis; Seed yield; Yield components 
Doi: https://doi.org/10.33002/nr2581.6853.02042

\section{Introduction}

Sunflower is an important oilseed crop with high quality of edible oil. Sunflower hybrids are preferred by farmers, because of their uniformity, high yield performance, better quality and resistance to disease. Identification of superior parents for hybridization is an important step in plant breeding. Combining ability of parental lines should be estimated to find the best hybrid combinations. Furthermore, estimation of gene effects could be done by analysing combining ability values based on $\mathrm{F}_{1}$ mean values (Manivannan, Chandirakala and Abirami, 2015). Combining ability of inbred lines could be estimated with various methods such as top cross. Line $\times$ tester analysis is an extension of this method in which several testers are used (Kempthorne, 1957).

Heterosis of sunflower has been exploited only over the past few decades. Hybrid sunflower became a reality with the discovery of cytoplasmic male sterility and effective male fertility restoration system during 1970. Hybrid vigour has been the main driving force for acceptance of this oilseed crop. Utilization of heterosis has allowed sunflower to become one of the major oilseeds in many countries of Eastern and Western Europe, Russia and South America and is an important crop in the USA, Australia, South Africa, China, India and Turkey. Sunflower hybrid breeding has thus played a vital role in improvement of this crop. Increasing seed and oil yields is the top priority of most sunflower breeding programs. Getting benefit from use of heterosis is the main purpose in sunflower hybrid breeding.

In India, the sunflower is grown on about 0.55 million ha (Anonymous, 2018) and mostly grown in the states of Karnataka, Maharashtra, Andhra Pradesh and Tamil Nadu with potential scope of growing in the non-traditional areas like West Bengal (Dutta, 2015). In West Bengal, sunflower is second important oilseed crop after rapeseed-mustard during rabi (summer) season and it was grown on about 16,000 ha in last rabi season (2016-17 Annual Report, Department of Agriculture, Government of West Bengal). Due to short winter spell and delayed and heavy rainfall during rainy season, the sowing of mustard was delayed which ultimately reduced the production of rapeseedmustard (Dutta, 2011). The delayed sowing also invites the insect pests in most of the years. Sunflower being a photoperiod natural crop has wide scope to replace the rapeseed-mustard cultivation with high yield potentiality (Dutta, 2015), where sunflower proved to be fitted with good seed and oil yield potentiality.

The main objectives of sunflower breeding programs are the development of productive $\mathrm{F}_{1}$ hybrids with high seed and oil yield. Sunflower oil yield is determined as the product of seed yield per unit area and the seed oil percentage. Therefore, consideration of both components is important to breeding for high oil yield (Fick and Miller, 1997). National sunflower hybrid breeding programme is a continuous programme which started in India early 1980s. Sunflower hybrid breeding was started economically in discovering CMS (Leclercq, 1969) and restorer genes (Kinman, 1970). Combining ability and gene action depends on diverse CMS sources in sunflower (Helianthus annuus L.) (Miller, 1998; Jondhale, Goud and Praveenkumar, 2012).

\section{Materials and Methods}

The crossing was affected in the line $\mathrm{x}$ tester fashion and the resultant hybrids were subjected to combining ability studies. The experiment was conducted in randomized complete block design with three replicates for two years 2015-16 and 2016-17 at All India Coordinated Research Project 
(AICRP)-Sunflower, Nimpith Centre. Specific combining ability (sca) effects seed yield and other yield attributing agronomic traits that were studied in the sunflower hybrids. Four cytoplasmic male sterile lines were used as female lines while nine new male inbreeds were introduced as testers in the form of fertility restorers. The female lines were introduced from IIOR-ICAR, Hyderabad and from other AICRP Centres, while the male restorer inbred lines with good combining abilities were used as testers in the form of fertility restorers. $F_{1}$ hybrids were obtained by crossing each tester with each female inbred. The inbred lines and their $F_{1}$ hybrids differed significantly in their mean values of the traits under the present study.

The genotypes (parents and hybrids) were raised in Randomized Block Design with two replications wherein each replication was represented by three rows of 3 meter length. The soil texture was clay loam in "on station" plots. Three irrigations were provided during the cropping period. One foliar spray was given with boron @ $2 \mathrm{~g} /$ litre of water in ray floret stage. The rows per plot were five in number with a row spacing of $60 \mathrm{~cm}$ and plant to plant spacing was $30 \mathrm{~cm}$. Uniform dose of fertilizer of $80 \mathrm{~kg} \mathrm{~N}, 40 \mathrm{~kg} \mathrm{P}_{2} \mathrm{O}_{5}$ and $40 \mathrm{~kg} \mathrm{~K}_{2} \mathrm{O}$ per ha was applied. The germinated seed of sunflower used and one per hill were maintained throughout the cropping period. The data was recorded in ten randomly selected plants from each plot of all replications on the following characters viz., days to 50\% flowering, days to maturity, plant height at harvest $(\mathrm{cm})$, head diameter per plant $(\mathrm{cm})$, seed weight per head $(\mathrm{g}), 100$-seed weight $(\mathrm{g})$, husk (hull) content $(\%)$, volume weight $(\mathrm{g} / 100 \mathrm{cc})$. The seed yield $(\mathrm{kg} / \mathrm{ha})$, oil percentage and oil yield $(\mathrm{kg} / \mathrm{ha})$ were estimated on plot basis. The mean values were subjected to statistical analysis. In the very first year (2014-15), 36 of hybrids (developed from line $x$ tester matting design) were evaluated and next year, 2015-16 and 2016-17, 36 hybrids were evaluated for performance. This experiment was conducted at research farm in AICRP Sunflower, Nimpith Centre in Randomized Complete Block Design with three replications. The data pertaining to seed yield and other yield attributing traits for these test hybrids are presented in Table 4.

\section{Results and Discussions}

Heterosis is the increase or decrease in vigour of $\mathrm{F}_{1}$ generation over its mid or better parental value. One of the objectives of present study was to estimate the extent of heterosis for various characters and to isolate promising hybrids over standard check hybrids for seed yield and oil content for commercial exploitation. For our purposes, we will define heterosis or hybrid vigour as the difference between the hybrid and the mean of the two parents (Falconer and Mackay, 1996). The nature and magnitude of heterosis for seed yield and its component characters is helpful in heterosis breeding. The maximum utilization of heterosis is possible when the variance due to both additive and non-additive gene actions are fully exploited since they play a significant role in determining the magnitude of expression of yield and its component.

Among the 36 sunflower hybrids, the heterosis was observed from 1.07 per cent (P-2-7-1A X R $104)$ to 12.11 per cent (CMS-10A X EC-601958) for days to 50\% flowering; 31.46 per cent (P-27-1A X R-630) to 87.26 per cent (CMS-10A X EC-601978) for plant height; 54.07 per cent (CMS107 AX EC-601958) to 120.3 per cent (CMS-10A X EC-601978) for head diameter; 81.50 per cent (P-2-7-1A X R-630) to 233.15 per cent (CMS-10 A X R-104) for seed yield (kg/ha); 54.5 per cent (P-89-1A X R-630) to 252.2 per cent (CMS-10A X EC-601958) for number of filled seed/head; $3.14 \%$ per cent (CMS-10 AXR-138-2) to $13.38 \%$ per cent (P-2-7-1A X R-1-1) for seed filling \%; -15.3 per cent (CMS-10A XR-6D-1) to 13.38 per cent (P-2-7-1A X R-1-1) for 100 seed weight(g); 
Doi: https://doi.org/10.33002/nr2581.6853.02042

-19.35 per cent (CMS-10A X R-6D-1) to 46.7 per cent(CMS-10 A X R-104) for 100 seed kernel weight (g); -16.2 3per cent (CMS-10A X R-107) to 30.54 per cent (P-89-1A XR-1-1) for hull content; -9.13 per cent (CMS-10 A X R-630) to 15.24 per cent (CMS-107A X R-104) for volume weight (g/100 cc); -9.80 per cent (P-89-1A X R-1-1) to 7.02 per cent (CMS-10A X R-107) for oil content \%; and for oil yield (kg/ha) from 46.0 per cent (P-89-1A X EC-601978) to 199.6 per cent (CMS-10A X EC-601958).

From the experiment it was revealed that the average heterosis of $8.9 \%$ for days to $50 \%$ flowering, $65.1 \%$ for plant height, $80.3 \%$ for head diameter, $139.8 \%$ for seed yield $(\mathrm{kg} / \mathrm{ha}), 107.5 \%$ for number of filled seed/head, $5.9 \%$ for seed filling $\%, 10.8 \%$ for 100 seed weight, $12.1 \%$ for 100 seed kernel weight, $6.5 \%$ for hull content, $4.7 \%$ for volume weight $(\mathrm{g} / 100 \mathrm{cc}), 0.1 \%$ for oil content $(\%)$ and $140.4 \%$ for oil yield (kg/ha), respectively (Table 2). Among the 36 sunflower hybrids, significant negative heterosis and lower values of performance per se for days to $50 \%$ flowering were recorded in sunflower hybrids viz., P-2-7-1A X R-138-2 (66 days), P-2-7-1A X R-104 (66 days), P-89-1A X R-12-96 (68 days) and CMS-10A XR-630 (68 days), whereas fourteen crosses displayed significant positive heterosis. Higher values of performance per se for days to $50 \%$ flowering was recorded in sunflower hybrids viz., P-2-7-1A X EC-601958 (73 days), P-89-1A X EC-601958 (72 days) followed byP-2-7-1A X R-6D-1(70 days) and CMS-10 A X R-104 (71 days) respectively (Table-3). It was revealed that positive heterosis and lower values of performance per se for plant height was observed in sixteen cross combinations, among them P-2-7-1A X R-630 (143.3 cm), P2-7-1A XR-138-2 (146.7 cm), P-2-7-1A X EC-601978 (150.2 cm), P-2-7-1A X R-104 (152 cm), P-89-1A X EC-601958 (153cm), CMS-10A X R-104 (157cm), CMS-10A X EC-601958 (147 cm),CMS-10A X EC-601978 (152 cm), CMS-107A X EC-601958 (148 cm), CMS-107 A X EC$601958(145 \mathrm{~cm})$ were found promising ones (Table 4).

Seventeen crosses displayed significant positive heterosis for head diameter, as per the positive heterosis and performance per se, the highest value was recorded in P-2-7-1A X R-138-2 (15.4 $\mathrm{cm})$, followed by CMS-107A X R-12-96 (15.8 cm), CMS-107A X R-104 (15.7 cm), CMS-10A X R-12-96 (15.7 cm), CMS-107A X R-630 (15.4 cm), CMS-10 A X R-104 (15.4 cm), P-89-1A XR1-1 $(15.3 \mathrm{~cm})$, respectively (Table $3 \&$ Table 4$)$. For number of filled seeds per head, significant positive heterosis was recorded in fifteen crosses among them, as per the performance per se, CMS10A X R-12-96 (810), P-89-1A X R-104 (798), CMS-10A X EC-601958 (793), CMS-10A X EC601978 (787), CMS 107A XR-630 (781), P-2-7-1A X R-6D-1 (789)and P-89-1A X EC-601958 (772) were found promising ones. For autogamy (seed filling) (\%), significant positive sca effects and positive heterosis were recorded in twelve crosses among them, as per the performance per se, P-89-1A X EC-601958 (90.2), CMS-10A X R-1-1 (89.2), CMS-107AX EC-601958 (89.2), CMS107A X EC-601978 (89.2) and CMS- 107A X R-138-2 (89.2) were found promising (Table 3 and Table 4).

For 100 seed weight, very few crosses (eleven) displayed significant and positive heterosis. Among them, as per the performance per se, P-2-7-1A X R-1-1 (6.6) and P-2-7-1A X R-104 (6.6) followed by P-2-7-1A X EC-601978 (6.2) and P-2-7-1A X EC-601958 (6.04 g) were found promising ones. For 100 seed kernel weight (g), positive heterosis was observed in only thirteen crosses; as per the performance per se, P-2-7-1A X R-1-1 (4.41), P-2-7-1A X R-104 (4.35), and P-2-7-1A X EC601978 (4.25) are very promising ones. For hull content $(\%)$, the lower values are desirable because hull content $(\%)$ has negative association with oil content and seed yield. Among the hybrids, very few (only twelve) crosses displayed significant negative heterosis for the same trait. Among the 
hybrids, as per the negative heterosis and performance per se, the hybrids viz., CMS-10A X R-107 (28.8), CMS-10A X R-630 (30.8\%), CMS-107A X R-104 (30.9\%), CMS-10A X R-138-2 (32.2), CMS-107A X EC-6019178 (32.2\%) were found very promising. For volume weight (g/100 cc), it was revealed that only seven crosses displayed significant positive heterosis. With regards to performance per se, P-89-1A XR-138-2 (40.3) and CMS-107 X R-630 (40.2) followed by P-2-71A X R-6D-1 (39.8), CMS-10A X R-6D-1 (39.8), P-89-1A X R-6D-1 (39.7), CMS-107 X R-104 (39.6), P-89-1A X R-104 (39.3) were found promising ones (Table 3 and Table 4).

For seed oil content (\%), only seventeen crosses displayed significant positive heterosis for the said trait, among them, with regards to performance per se, the hybrids, viz. P-2-7-1A X R-6D-1 (37.6), P-89-1A X EC-601978 (37.7), P-89-1A X EC-601958 (37.1), and CMS-10A X R-107 (37.7) sunflower hybrids were the promising ones. Among the 36 sunflower hybrids, as regards to the seed yield and oil yield ( $\mathrm{kg} / \mathrm{ha}$ ), fifteen crosses displayed significant positive heterosis. Among them, with regards to performance per se, P-2-7-1A X EC-601958 (seed yield of $2304 \mathrm{~kg} / \mathrm{ha}$, oil yield of $795 \mathrm{~kg} / \mathrm{ha}$ ), CMS-10 A X R-104 (seed yield of $2175 \mathrm{~kg} / \mathrm{ha}$, oil yield of $722 \mathrm{~kg} / \mathrm{ha}$ ), P-891A X EC-601958 (2020 kg/ha, oil yield of $750 \mathrm{~kg} / \mathrm{ha})$, P-2-7-1A X R-6D-1 (1927 kg/ha, oil yield of $724 \mathrm{~kg} / \mathrm{ha})$, P-89-1A X R-104 (1968 kg/ha, oil yield of $722 \mathrm{~kg} / \mathrm{ha}$ ) were found very promising ones (Table 3 and Table 4).

The studies, as regards to heterosis and performance per se, revealed the best cross combination for semi-dwarf plant height coupled with good seed yield and oil content, P-2-7-1A X R-138-2 (66 days to flower, seed yield of $1932 \mathrm{~kg} / \mathrm{ha}$ and oil yield of $678 \mathrm{~kg} / \mathrm{ha}$ ), P-89-1A X R-12-96 (68 days to flower, seed yield of $1818 \mathrm{~kg} / \mathrm{ha}$ and oil yield of $667 \mathrm{~kg} / \mathrm{ha}$ ), CMS-10A X R-630 (66 days to flower, seed yield of $1798 \mathrm{~kg} / \mathrm{ha}$ and oil yield of $662 \mathrm{~kg} / \mathrm{ha}$ ), P-2-7-1A X R-104 (66 days to flower, seed yield $1752 \mathrm{~kg} / \mathrm{ha}$ and oil yield $628 \mathrm{~kg} / \mathrm{ha}$ ), respectively, showed negative heterosis for days to $50 \%$ flowering and significantly positive heterosis for seed yield and were involved type $\mathrm{H} \times \mathrm{L}$ and $\mathrm{L} \times \mathrm{H}$ (the parents with low gca effects). The above said crosses involved at least one parent with high gca effects having high seed yield at per se performance. The hybrid vigour and significant heterosis for economic trait can be exploited for commercial purpose. Such type of good with significant heterosis for yield attributing in sunflower was reported by Gourishankar et al. (2007), Parmeshwarappa, Ram and Lingaraju (2008), Binodh, Manivannan and Varman (2008), Mohanasundaram, Manivannan and Vindhaiyavarman (2010); Karasu et al. (2010), Chandra, Ranganatha and Kumar (2013), Patil et al. (2012), Patil et al. (2017), Nandini et al. (2017), Tyagi, Dhillon and Bajaj (2013), Sahane et. al. (2017), Supriya et. al. (2017) and Nichal et. al. (2018).

\section{Conclusion}

The study reveals that the average heterosis of $8.9 \%$ for days to $50 \%$ flowering, $65.1 \%$ for plant height, $80.3 \%$ for head diameter, $139.8 \%$ for seed yield $(\mathrm{kg} / \mathrm{ha}), 107.5 \%$ for number of filled seed/head, $5.9 \%$ for seed filling $\%, 10.8 \%$ for 100 seed weight, $12.1 \%$ for 100 seed kernel weight, $6.5 \%$ for hull content, $4.7 \%$ for volume weight $(\mathrm{g} / 100 \mathrm{cc}), 0.1 \%$ for oil content $(\%)$ and $140.4 \%$ for oil yield ( $\mathrm{kg} / \mathrm{ha})$, respectively. In all cross, seed and oil yield $(\mathrm{kg} / \mathrm{ha})$ traits and other desirable traits, P-2-7-1A, CMS-10 A, P-89-1A, EC-601958, R-104, EC-601978, R-138-2, R-630 and R-6D1 were involved more frequently. The studies revealed that, as regards to sca effects and performance per se, the best cross combination for semi-dwarf plant height coupled with good seed yield and high oil content, the superior cross combinations were P-2-7-1A X R-138-2, P-89-1A X R-12-96, CMS-10A X R-630, P-2-7-1A X R-104, respectively, showed significantly high sca 
effects (negative) for days to $50 \%$ flowering, and significantly positive sca effects for seed yield and were involved type $\mathrm{H} \times \mathrm{L}$ and $\mathrm{L} \times \mathrm{H}$ (the parents with low gca effects).

\section{Acknowledgement}

The authors are highly thankful to AICRP-Sunflower System, IIOR-ICAR, Hyderabad for continuous financial and academic support and guidance throughout the research programme.

\section{References}

Anonymous (2018). https://www.sunflowernsa.com/stats/worldsupply.

Binodh, A.K., Manivannan, N. and Varman, P.V. (2008). Combining ability analysis for yield and its contributing character in sunflower (Helianthus annuusL). Madras Agric. J., 95(7-12): 124-132.

Chandra, B.S., Ranganatha, A.R.G. and Kumar, S. (2013). Heterosis studies for yield and it's components in sunflower hybrids over locations. Madras Agric. J., 100(13): 23-29.

Dutta A. (2011). Effects of sowing dates on yield and yield components of hybrid sunflower $(H$. annuus L.) in non-traditional areas of West Bengal. Journal of Crop and Weed, 7(2): 216228.

Dutta, A. (2015). Performance of sunflower hybrids (H. annuus L.) under West Bengal condition. Journal of Oilseeds Research, 32(2): 129-132.

Falconer, D.S. and Mackay, T.F.C. (1996). Introduction to quantitative genetics. 4th edition. England: Longman Group Limited.

Fick, G.N. and Miller, J.F. (1997). Sunflower Breeding. In: Sunflower Technology and Production (A.A. Schneiter ed). Madison, USA, 395-440.

Gourisankar, V., Ganesh, M., Ranganatha, A.R.G., Suman, A. and Sridhar. V. (2007). Combining ability studies in diverse CMS sources in sunflower. Indian Journal of Agric. Res., 41(3): 171-176.

Jondhale, A.S., Goud, I.S. and Praveenkumar, B. (2012). Combining Ability and Gene Action Studies in Diverse CMS Sources in Sunflower (Helianthus annuus L.). International Journal of Science and Research, 3(12): 2183-2187.

Jondhale, A.S., Goud, I.S. and Praveenkumar, B. 2012. Combining Ability and Gene Action Studies in Diverse CMS Sources in Sunflower (Helianthus annuus L.) International Journal of Science and Research,3(12): 2183-2187.

Karasu, A., Mehmet, O., Sincik, M., Goksoy, A.T. and Tarun, Z.M. (2010). Combining ability and heterosis for yield and yield components in sunflower. Nat. Bot. Hort. Agrobot. Cluj., 38(3): 541-542.

Kinman, M.L. (1970). New development in the USDA and State Experiment Station, Sunflower breeding programme. In: Proc. of the Fourth Int. Sunflower Conference, Memphis, Tennessa, pp.181-183.

Kmpthorne, O. (1957). An Introduction of Genetics Statistics. Iowa: The Iowa University Press.

Leclercq, P. (1969). Line sterile cytoplasmic quechezk tournesol. Ann. Amelior Planta, 12: 99-106.

Manivannan, N., Chandirakala, R. and Abirami, S. (2015). Evaluation of new CMS lines for heterosis breeding in sunflower (Helianthus annuus L.). Advances in Life Sciences, 5(5): 1909-1912.

Miller, J.F. (1998). Oilseed and heterosis. Tektran. United States Dept. Agric. Agric. Res. Service. 
Mohansundaram, K, Manivannan, N. and Vindhaiyavarman, P. (2010). Combining ability analysis for seed yield and its components in sunflower (Helianthus annuus L.). Elec. J. Pl. Breed., 4: 864-865.

Nandini, C., Shadakshari, Y.G., Pushpa, D., Puttarangaswamy, K.T. and Kumar, V. (2017). Genetic diversity analysis in diversified CMS and restorer lines in sunflower (Helianthus annuus L.). Int. J. Curr. Microbiol. App. Sci., 6(10): 3185-3189

Nichal, S.S., Vaidya, E.R., Fatak, S.U. and Kharat, B.S. (2018). Combining ability analysis in Sunflower (Helianthus annuus L.). Mulilogic in Science, VIII(XXIV): 28-35.

Parameshwarappa, K.G., Ram, J. and Lingaraju, B.S. (2008). Heterosis and combining ability for seed yield, oil content and other agronomic traits involving mutant restorer lines in sunflower (Helianthus annuusL.). J. Oilseeds Res., 25(1): 8-12.

Patil, T.R., Gouds, A., Kulkarni, V. and Bankar, C. (2012). Combining ability and gene action studies for seed yield and it's components in sunflower (Helianthus annuus L.). E.J. Plant Breeding, 3(3): 861-867.

Patil, T.R., Kulkarni, P.G.V., Shankergoud, I., Kenganal, M. and Diwan, J.R. (2017). Combining ability studies in restorer lines of sunflower (Helianthus annuus L.). Journal of Applied and Natural Sciences, 9(1): 603-608.

Sahane, G.S., Nichal, S.S., Vaidya, E.R. and Girnare, V.B. (2017). Heterotic studies in Sunflower (Helianthus annuus L.) through Line $\mathrm{x}$ Tester analysis. Trends in BioScience, 10(42): 87788788.

Supriya, S.M., Kulkarni, V.V., Ranganatha, C.N. and Suresha, P.G, (2017). Quantitative Analysis of Oil Yield and Its Components in Newly Developed Hybrids of Sunflower (Helianthus annuus L.). Int. J. Curr. Microbiol. App. Sci., 6(8): 3088-3098.

Tyagi, N., Dhillon, S. K. and Bajaj, R.K. (2013). Estimates of heterosis for oil content in sunflower (Helianthus annuus L.). $16^{\text {th }}$ Punjab Science Congress, pp.72. 
Table 1: Combined analysis of variance for line $\mathrm{X}$ tester for yield and yield attributing traits

\begin{tabular}{|c|c|c|c|c|c|c|c|c|c|c|c|c|c|c|}
\hline $\begin{array}{l}\text { Source of } \\
\text { variation }\end{array}$ & d.f. & $\begin{array}{c}\text { Days to } \\
50 \% \\
\text { flowering }\end{array}$ & $\begin{array}{c}\text { Plant heigh } \\
(\mathrm{cm})\end{array}$ & \begin{tabular}{|c|} 
Head \\
diameter \\
$(\mathrm{cm})$ \\
\end{tabular} & $\begin{array}{c}\text { No. of filled } \\
\text { grain/hd }\end{array}$ & $\begin{array}{l}\text { Auto- } \\
\text { gamy \% }\end{array}$ & $\begin{array}{c}100 \text { seed } \\
\text { wt. (g) }\end{array}$ & $\begin{array}{c}100 \\
\text { kernel } \\
\text { wt. (g) }\end{array}$ & $\begin{array}{c}\text { Hull } \\
\text { content } \\
\% \\
\end{array}$ & $\begin{array}{c}\text { Vol. wt. } \\
\text { (g/100 } \\
\text { cc) }\end{array}$ & $\begin{array}{c}\text { Seed yield/ } \\
\text { plant }(\mathrm{g})\end{array}$ & $\begin{array}{l}\text { Seed yield/ } \\
\text { (kg/ha) }\end{array}$ & $\begin{array}{c}\text { Oil } \\
\text { content } \\
\% \\
\end{array}$ & $\begin{array}{l}\text { Oil yield } \\
(\mathrm{kg} / \mathrm{ha})\end{array}$ \\
\hline Location & 1 & $24.25 * *$ & $1729.7 * *$ & $13.45 * *$ & $33467.8 * *$ & $260.3 * *$ & 0.612 & 0.97 & 1.85 & $207.41 * *$ & $289.0 * *$ & $528696.2 * *$ & $59.64 * *$ & $66543.5^{* *}$ \\
\hline Repl./Loc. & 2 & 17.02 & $283.9 *$ & 2.00 & $10101.5^{* *}$ & $19.34 * *$ & 0.78 & 0.027 & 2.57 & $11.10 * *$ & $76.49 * *$ & $240075.5 * *$ & 3.05 & $36602.7 * *$ \\
\hline Parents & 12 & $54.83 * *$ & $356.1 * *$ & $2.28 *$ & $32009.7 * *$ & $44.14 * *$ & $2.59 * *$ & 0.832 & $7.97 * *$ & 4.03 & $34.48 * *$ & $74735.3 * *$ & $8.37 * *$ & $14864.8^{* *}$ \\
\hline Line & 3 & $28.36 * *$ & $313.4 * *$ & $4.02 *$ & $1843.1 * *$ & $13.93 * *$ & $2.03 * *$ & 0.554 & $8.94 * *$ & 1.76 & $10.94 * *$ & $32852.2 * *$ & 3.54 & $26755.0 * *$ \\
\hline Tester & 8 & $38.46 * *$ & $374.0 * *$ & $1.90^{*}$ & $38434.6^{* * *}$ & $39.27 * *$ & 1.81 & 0.807 & $8.43 * *$ & 3.64 & $42.51 * *$ & $99355.5 * *$ & $11.18 * *$ & $18374.5 * *$ \\
\hline $\mathrm{L} v s \mathrm{~T}$ & 1 & $265.1 * *$ & $340.1 * *$ & 0.142 & $71110.3 * *$ & $173.8 * *$ & $10.53 * *$ & $1.870^{*}$ & 1.42 & $13.96 * *$ & $40.86 * *$ & $3424.0 * *$ & 0.351 & $23354.0 * *$ \\
\hline Hybrid & 35 & $35.48 * *$ & $438.6 * *$ & $2.48 * *$ & $38861.2 * *$ & $36.28 * *$ & 1.66 & 1.085 & $41.42 * *$ & $9.88 * *$ & $41.80 * *$ & $127157.2 * *$ & $10.63 * *$ & $14507.3 * *$ \\
\hline Parents $v s \mathrm{~F}_{1} \mathrm{~S}$ & 1 & $730.2 * *$ & $120811.2 * *$ & $1617.7 * *$ & $380513.6 * *$ & $1266.4 * *$ & $22.33 * *$ & $10.54 * *$ & $179.1 * *$ & $139.5 * *$ & $11346.2 * *$ & $\begin{array}{l}39053520.1 \\
* *\end{array}$ & 0.324 & $4193951.2 * *$ \\
\hline Parents x Loc. & 12 & 3.36 & $198.2 * *$ & 0.685 & $1685.7 * *$ & 2.45 & 0.0037 & 0.008 & 1.98 & $12.25 * *$ & $8.19 * *$ & $7206.2 * *$ & 0.191 & $2277.0 * *$ \\
\hline Line x Loc. & 3 & 5.70 & $121.4 * *$ & 0.005 & $153.7 *$ & 0.200 & 0.0009 & 0.002 & 0.511 & $13.75 * *$ & 0.171 & 536.0 & 0.042 & 66.62 \\
\hline T x Loc. & 8 & 0.005 & $127.4 * *$ & 1.02 & $2272.7 * *$ & 0.0008 & 0.006 & 0.001 & 0.0005 & 5.95 & 6.77 & $10055.4 * *$ & 0.0045 & $1597.5^{* *}$ \\
\hline$(\mathrm{L} v s \mathrm{~T}) \times \mathrm{Loc}$ & 1 & $23.2 * *$ & $995.3 * *$ & 0.013 & $1585.5 * *$ & $28.74 * *$ & 0.037 & 0.08 & $22.22 * *$ & $58.20 * *$ & $43.69 * *$ & $4423.9 * *$ & 2.38 & $14347.2 * *$ \\
\hline Hybrid x Loc & 35 & 0.09 & 0.278 & 0.009 & $2842.1 * *$ & 0.022 & 0.0014 & 0.0004 & 2.28 & $22.24 * *$ & $41.85^{* *}$ & $565.1 * *$ & 0.143 & $326.46 * *$ \\
\hline $\begin{array}{l}\left(\text { Parents } v s \mathrm{~F}_{1}\right) \\
\mathrm{x} \text { Loc }\end{array}$ & 1 & $13.30 * *$ & $319.1 * *$ & $2.81 * *$ & $13364.6^{* *}$ & $15.25 * *$ & 0.018 & 0.007 & 1.51 & $15.87 * *$ & $79.67 * *$ & $10039.8 * *$ & 1.05 & $23653.4 * *$ \\
\hline Error & 96 & 0.192 & 3.34 & 0.028 & 224.2 & 0.268 & 0.24 & 0.145 & 0.87 & 3.16 & 0.726 & 180.4 & 0.145 & 33.6 \\
\hline
\end{tabular}

$*$, **: Significant at $\mathrm{P}=0.05$ and 0.01 , respectively 
Table 2: Comparison of overall mean performance of parents and $F_{1} s$ and average heterosis for yield attributing traits in sunflower

\begin{tabular}{|c|c|c|c|c|c|c|}
\hline \multirow{2}{*}{ Character } & \multicolumn{2}{|r|}{ Parents } & \multicolumn{2}{|r|}{$\mathrm{F}_{1}$} & \multirow{2}{*}{ Mean $F_{1}-$ Mean } & \multirow{2}{*}{$\begin{array}{r}\text { Average heterosis } \\
(\%)\end{array}$} \\
\hline & Mean & Range & Mean & Range & & \\
\hline Days to $50 \%$ flowering & 62.50 & $56.7-70.16$ & 68.08 & $62.68-73.15$ & 5.58 & 8.9 \\
\hline Plant height(cm.) & 88.78 & $78.3-100.6$ & 146.60 & $142.90-176.5$ & 57.82 & 65.1 \\
\hline Head diameter $(\mathrm{cm})$ & 8.11 & $7.10-9.45$ & 14.62 & $13.30-15.80$ & 6.51 & 80.3 \\
\hline Seed yield (kg/ha) & 739.30 & $625-941$ & 1772.51 & $1484.5-2303.4$ & 1033.21 & 139.8 \\
\hline No. of filled seeds/head & 309.32 & $251-450$ & 641.82 & $444.45-880.50$ & 332.5 & 107.5 \\
\hline Autogamy (seed filling) $\%$ & 81.12 & $75.3-85.3$ & 85.94 & $80.28-90.12$ & 4.82 & 5.9 \\
\hline 100 Seed weight $(\mathrm{g})$ & 4.62 & $3.16-6.10$ & 5.12 & $4.26-5.76$ & 0.5 & 10.8 \\
\hline 100 kernel weight $(\mathrm{g})$ & 2.94 & $2.02-3.65$ & 3.32 & $2.57-4.16$ & 0.38 & 12.9 \\
\hline Hull content $\%$ & 33.91 & $31.05-36.15$ & 36.1 & $30.97-41.50$ & 2.19 & 6.5 \\
\hline Volume weight $(\mathrm{g})$ & 34.86 & $32.68-36.28$ & 36.5 & $34.50-39.62$ & 1.64 & 4.7 \\
\hline Oil \% & 35.38 & $33.25-37.60$ & 35.4 & $34.53-37.40$ & 0.02 & 0.1 \\
\hline Oil yield (kg/ha) & 260.68 & 198.6-301.2 & 626.7 & $507.6-795.5$ & 366.02 & 140.4 \\
\hline
\end{tabular}


Table 3: Performance per se of the sunflower hybrids $\left(\mathrm{F}_{1}\right)$ for yield attributing traits in sunflower

\begin{tabular}{|c|c|c|c|c|c|c|c|c|c|c|c|c|c|}
\hline $\begin{array}{l}\text { Sl. } \\
\text { No }\end{array}$ & Hybrid combination & $\begin{array}{c}\text { Days to } \\
50 \% \\
\text { flowering }\end{array}$ & $\begin{array}{l}\text { Plant } \\
\text { height } \\
(\mathrm{cm})\end{array}$ & $\begin{array}{c}\text { Head } \\
\text { diameter } \\
(\mathrm{cm})\end{array}$ & $\begin{array}{l}\text { Seed yield } \\
(\mathrm{kg} / \mathrm{ha})\end{array}$ & $\begin{array}{c}\text { No. of } \\
\text { filled } \\
\text { seeds/ } \\
\text { head } \\
\end{array}$ & $\begin{array}{c}\text { Autogam } \\
\text { y (seed } \\
\text { filling) } \%\end{array}$ & $\begin{array}{c}100 \\
\text { seed } \\
\text { weight } \\
(\mathrm{g}) \\
\end{array}$ & $\begin{array}{c}100 \\
\text { kernel } \\
\text { wt. (g) }\end{array}$ & $\begin{array}{c}\text { Hull } \\
\text { content } \\
(\%)\end{array}$ & $\begin{array}{c}\text { Vol. wt. } \\
\text { (g/100 } \\
\text { cc) }\end{array}$ & $\begin{array}{c}\text { Oil } \\
\text { content } \\
\%\end{array}$ & $\begin{array}{c}\text { Oil yield } \\
(\mathrm{kg} / \mathrm{ha})\end{array}$ \\
\hline 1. & P-2-7-1A X R-6D-1 & 70.2 & 151.0 & 15.6 & 1927.8 & 789.2 & 87.2 & 5.45 & 3.67 & 37.0 & 39.9 & 37.6 & 723.9 \\
\hline 2. & P-2-7-1A X R-12-96 & 66.2 & 155.2 & 15.2 & 1739.0 & 528.5 & 85.2 & 5.97 & 3.79 & 36.6 & 38.0 & 35.6 & 618.2 \\
\hline 3. & P-2-7-1A X R-630 & 65.7 & 143.4 & 14.1 & 1692.8 & 679.8 & 84.2 & 4.65 & 2.91 & 39.3 & 37.8 & 35.5 & 600.9 \\
\hline 4. & P-2-7-1A X R 601958 & 73.2 & 159.6 & 15.1 & 2303.4 & 691.5 & 88.2 & 6.25 & 4.15 & 34.7 & 36.4 & 34.5 & 795.4 \\
\hline 5. & P-2-7-1A X EC-601978 & 69.7 & 150.3 & 14.2 & 1837.0 & 597.3 & 87.2 & 6.04 & 3.95 & 36.2 & 37.5 & 35.3 & 649.0 \\
\hline 6. & P-2-7-1A XR-138-2 & 66.2 & 146.8 & 15.4 & 1932.8 & 628.6 & 87.2 & 5.37 & 3.44 & 36.5 & 37.7 & 35.1 & 678.4 \\
\hline 7. & P-2-7-1A X R-1-1 & 67.7 & 146.0 & 13.7 & 1622.0 & 444.4 & 89.2 & 6.63 & 4.41 & 34.2 & 36.6 & 35.5 & 575.8 \\
\hline 8. & P-2-7-1A x R -107 & 70.2 & 159.4 & 14.4 & 1798.0 & 563.7 & 88.2 & 5.44 & 3.53 & 36.0 & 37.5 & 35.7 & 641.9 \\
\hline 9. & P-2-7-1A X R -104 & 66.2 & 145.0 & 13.8 & 1752.8 & 480.7 & 89.2 & 6.58 & 4.35 & 34.1 & 37.1 & 35.8 & 627.5 \\
\hline 10 & P-89-1A XR-6D-1 & 64.2 & 142.9 & 13.6 & 1573.0 & 558.5 & 88.2 & 4.93 & 3.12 & 36.3 & 39.7 & 37.5 & 589.9 \\
\hline 11. & P-89-1A XR-12-96 & 67.7 & 161.5 & 14.1 & 1817.7 & 637.8 & 85.2 & 5.10 & 3.22 & 36.3 & 38.8 & 36.7 & 667.1 \\
\hline 12. & P-89-1A X R-630 & 64.2 & 150.7 & 14.3 & 1484.5 & 604.1 & 80.3 & 5.01 & 3.22 & 37.5 & 38.1 & 34.2 & 507.0 \\
\hline 13. & P-89-1A XEC-601958 & 72.2 & 153.4 & 15.1 & 2020.0 & 772.7 & 86.2 & 4.70 & 3.12 & 34.0 & 38.0 & 37.1 & 749.4 \\
\hline 14. & P-89-1A X EC-601978 & 68.7 & 145.7 & 13.5 & 1682.00 & 606.0 & 90.1 & 5.36 & 3.59 & 33.7 & 37.8 & 37.7 & 633.6 \\
\hline 15. & P-89-1A XR-138-2 & 64.2 & 152.9 & 13.2 & 1660.7 & 556.3 & 80.3 & 5.13 & 3.27 & 37.9 & 40.3 & 36.5 & 606.2 \\
\hline 16. & P-89-1A X R-1-1 & 70.2 & 148.7 & 15.3 & 1910.2 & 703.9 & 84.2 & 4.80 & 2.84 & 41.5 & 38.1 & 35.8 & 682.9 \\
\hline 17. & 89-1A XR-107 & 68.7 & 160.4 & 14.3 & 1647.5 & 679.9 & 89.2 & 4.49 & 2.78 & 38.5 & 38.8 & 35.5 & 584.9 \\
\hline 18. & P-89-1A X R-104 & 70.2 & 162.0 & 15.2 & 1967.7 & 799.1 & 84.2 & 4.45 & 2.76 & 36.8 & 39.3 & 36.7 & 722.1 \\
\hline 19. & CMS-10A XR-6D-1 & 62.7 & 160.7 & 14.2 & 1521.7 & 677.0 & 87.7 & 4.10 & 2.50 & 39.3 & 39.8 & 35.3 & 536.4 \\
\hline 20. & CMS-10A X R-12-96 & 71.2 & 168.0 & 15.7 & 1982.7 & 810.5 & 84.2 & 4.55 & 2.80 & 38.2 & 37.4 & 34.6 & 685.4 \\
\hline 21. & CMS-10 A XR-630 & 66.3 & 159.8 & 13.8 & 1798.0 & 658.2 & 83.3 & 5.31 & 3.70 & 30.9 & 33.0 & 36.8 & 661.7 \\
\hline 22. & CMS-10A X EC-601958 & 71.0 & 147.1 & 14.2 & 1859.0 & 793.3 & 86.2 & 4.76 & 3.14 & 38.3 & 37.5 & 34.2 & 635.8 \\
\hline 23. & CMS-10A X EC-601978 & 70.0 & 152.9 & 15.4 & 1848.0 & 787.5 & 88.2 & 4.59 & 2.84 & 39.1 & 38.0 & 35.0 & 645.9 \\
\hline 24. & CMS-10 AXR-138-2 & 63.0 & 161.0 & 14.8 & 1622.0 & 538.8 & 78.3 & 5.39 & 3.71 & 32.3 & 36.1 & 36.9 & 598.5 \\
\hline 25. & CMS-10A XR-1-1 & 63.5 & 156.2 & 14.4 & 1547.0 & 527.7 & 89.2 & 5.36 & 3.57 & 34.1 & 37.6 & 36.9 & 570.8 \\
\hline 26. & CMS-10A X R-107 & 65.5 & 152.1 & 14.0 & 1673.5 & 606.7 & 87.2 & 4.95 & 3.57 & 28.8 & 35.7 & 36.5 & 630.4 \\
\hline 27. & CMS-10 A X R-104 & 69.5 & 157.9 & 15.4 & 2175.2 & 701.0 & 86.2 & 5.62 & 3.28 & 35.7 & 37.6 & 34.6 & 751.5 \\
\hline 28. & CMS-107 A X R-6D-1 & 67.5 & 162.3 & 14.7 & 1791.7 & 734.3 & 84.2 & 4.55 & 3.06 & 33.7 & 35.4 & 35.6 & 636.9 \\
\hline
\end{tabular}




\begin{tabular}{|c|c|c|c|c|c|c|c|c|c|c|c|c|c|}
\hline 29. & CMS-107A X R-12-96 & 73.5 & 178.6 & 15.8 & 1643.0 & 677.8 & 85.2 & 4.30 & 2.61 & 40.6 & 38.1 & 33.0 & 541.4 \\
\hline 30. & CMS-107A XR-630 & 70.5 & 175.9 & 15.4 & 1864.5 & 781.5 & 80.3 & 4.26 & 2.61 & 39.6 & 40.2 & 35.7 & 665.6 \\
\hline 31 & $\begin{array}{l}\text { CMS-107 AX EC- } \\
601958\end{array}$ & 70.5 & 148.7 & 13.8 & 1781.7 & 557.0 & 89.2 & 5.74 & 3.90 & 33.4 & 38.2 & 36.8 & 655.7 \\
\hline 32 & $\begin{array}{l}\text { CMS-107A X EC- } \\
601978\end{array}$ & 70.5 & 145.1 & 13.3 & 1778.0 & 563.5 & 89.3 & 5.60 & 3.85 & 32.3 & 37.1 & 36.3 & 645.4 \\
\hline 33 & CMS-107A X R-138-2 & 66.5 & 168.1 & 14.4 & 1610.7 & 636.3 & 89.1 & 4.70 & 3.11 & 34.7 & 36.8 & 37.4 & 602.4 \\
\hline 34 & CMS-107A X R-1-1 & 65.5 & 161.1 & 15.3 & 1622.0 & 588.6 & 86.2 & 5.26 & 3.57 & 33.4 & 35.7 & 34.5 & 560.1 \\
\hline 35 & CMS-107A XR-107 & 69.5 & 169.0 & 15.4 & 1685.7 & 629.3 & 85.2 & 4.85 & 3.14 & 37.1 & 36.6 & 35.5 & 597.6 \\
\hline 36 & CMS-107A X R-104 & 70.6 & 176.0 & 15.7 & 1638.7 & 515.2 & 84.8 & 5.76 & 4.16 & 31.0 & 40.3 & 36.4 & 596.8 \\
\hline & G. Mean & 68.0 & 146.6 & 14.6 & 1772.5 & 641.8 & 85.9 & 5.1 & 3.3 & 36.1 & 36.5 & 35.4 & 626.7 \\
\hline & Lowest & $\begin{array}{l}62.68 \\
\text { 10A XR- } \\
6 \mathrm{D}-1\end{array}$ & \begin{tabular}{l|}
142.90 \\
P-89- \\
1A XR- \\
6D-1 \\
\end{tabular} & $\begin{array}{l}13.20 \\
\text { P-89-1A } \\
\text { XR-138- } \\
2\end{array}$ & $\begin{array}{l}1484.5 \\
\text { P-89-1A X } \\
\text { R-630 }\end{array}$ & $\begin{array}{l}444.45 \\
\text { P-2-7- } \\
\text { 1A X } \\
\text { R-1-1 }\end{array}$ & $\begin{array}{l}80.28 \\
107 A \\
\text { XR-630 }\end{array}$ & $\begin{array}{l}4.10 \\
\\
10 \mathrm{~A} \\
\mathrm{XR}- \\
6 \mathrm{D}-1 \\
\end{array}$ & $\begin{array}{l}2.50 \\
10 \mathrm{~A} \\
\mathrm{XR}- \\
6 \mathrm{D}-1 \\
\end{array}$ & $\begin{array}{l}28.84 \\
10 A^{X} \\
R-107\end{array}$ & $\begin{array}{l}32.95 \\
10 \mathrm{~A} \mathrm{X} \\
\mathrm{R}-630\end{array}$ & $\begin{array}{l}32.95 \\
107 A X \\
\text { R-12- } \\
96\end{array}$ & $\begin{array}{ll}507.6 & P- \\
89-1 A \quad X \\
R-630\end{array}$ \\
\hline & Highest & $\begin{array}{l}73.50 \\
\text { 107A X } \\
\text { R-12-96 }\end{array}$ & \begin{tabular}{l|}
178.50 \\
$107 A$ \\
X R- \\
$12-96$
\end{tabular} & $\begin{array}{l}15.80 \\
107 \mathrm{~A} \mathrm{X} \\
\text { R-12-96 }\end{array}$ & $\begin{array}{l}2303.4 \\
\text { P-2-7-1A } \\
\text { X R } \\
601958\end{array}$ & $\begin{array}{l}810.50 \\
10 A X \\
\text { R-12- } \\
96\end{array}$ & $\begin{array}{l}90.12 \\
\text { P-89-1A } \\
\text { X EC- } \\
601978\end{array}$ & $\begin{array}{l}6.63 \\
P-2-7- \\
1 A X \\
R-1-1\end{array}$ & $\begin{array}{l}4.41 \\
\text { P-2-7- } \\
1 \text { A X } \\
\text { R-1-1 }\end{array}$ & $\begin{array}{l}41.50 \\
\text { P-89- } \\
1 \mathrm{~A} \mathrm{X} \\
\text { R-1-1 }\end{array}$ & $\begin{array}{l}40.30 \\
\text { P-89- } \\
1 \mathrm{~A} \\
\text { XR- } \\
138-2\end{array}$ & $\begin{array}{l}37.55 \\
\text { P-2-7- } \\
\text { 1A X R- } \\
6 \mathrm{D}-1\end{array}$ & $\begin{array}{l}795.5 \\
\text { P-2-7-1A } \\
\text { X R } \\
601958\end{array}$ \\
\hline
\end{tabular}


Table 4: Heterosis (Mid Parent) of the Sunflower hybrids $\left(\mathrm{F}_{1}\right)$ for yield and yield contributing characters: Pooled: 2015-16 and 2016-17

\begin{tabular}{|c|c|c|c|c|c|c|c|c|c|c|c|c|c|}
\hline $\begin{array}{l}\text { Sl. } \\
\text { No. }\end{array}$ & Hybrid combination & $\begin{array}{c}50 \% \\
\text { flower- } \\
\text { ing }\end{array}$ & $\begin{array}{l}\text { Pl. ht. } \\
(\mathrm{cm})\end{array}$ & $\begin{array}{l}\text { Hd. dia. } \\
\text { (cm) }\end{array}$ & $\begin{array}{c}\text { Seed } \\
\text { yield } \\
(\mathrm{kg} / \mathrm{ha}) \\
\end{array}$ & $\begin{array}{l}\text { No. of } \\
\text { filled } \\
\text { grain/Hd }\end{array}$ & $\begin{array}{c}\text { Auto- } \\
\text { gamy } \\
\%\end{array}$ & $\begin{array}{c}100 \\
\text { seed } \\
\text { wt. (g) }\end{array}$ & $\begin{array}{c}100 \\
\text { kernels } \\
\text { wt. }(\mathrm{g}) \\
\end{array}$ & $\begin{array}{c}\text { H. } \\
\text { cont. } \%\end{array}$ & $\begin{array}{l}\text { Vol. wt. } \\
\text { (g/100 } \\
\text { cc) }\end{array}$ & Oil \% & $\begin{array}{c}\text { Oil yield } \\
(\mathrm{kg} / \mathrm{ha})\end{array}$ \\
\hline 1. & P-2-7-1A XR-6D-1 & 3.15 & $53.97 * *$ & $84.08 * *$ & $122.1 * *$ & $108.94 * *$ & $8.70^{*}$ & $5.9 *$ & $7.37 *$ & 4.39 & 3.35 & -0.56 & $123.5^{* *}$ \\
\hline 2. & P-2-7-1A XR-12-96 & 4.91 & $51.74 * *$ & $67.62 * *$ & $112.3 * *$ & $128.15 * *$ & $9.17 *$ & $-11.9 * *$ & - & $23.14 * *$ & $11.96 * *$ & $-7.61 * *$ & $80.9 * *$ \\
\hline 3. & P-2-7-1A XR-630 & 1.16 & $31.46^{* *}$ & $79.62 * *$ & $81.5 * *$ & $82.42 * *$ & 4.18 & $-5.7 *$ & $-5.52 *$ & $14.17 * *$ & $6.11 *$ & $5.81 *$ & $72.4 * *$ \\
\hline 4. & P-2-7-1A x R 601958 & $4.75^{*}$ & $55.10^{* *}$ & $68.45 * *$ & $165.8 * *$ & $165.93 * *$ & $6.53 *$ & $9.2 *$ & $15.84 * *$ & 1.43 & 4.82 & -0.20 & $157.4^{* *}$ \\
\hline 5. & $\begin{array}{l}\text { P-2-7-1A XEC- } \\
601718\end{array}$ & $8.71 * *$ & $66.63 * *$ & $97.64 * *$ & $211.4 * *$ & $145.64 * *$ & $7.72 *$ & $27.6^{* *}$ & $35.18 * *$ & 0.20 & 0.09 & -3.41 & $182.3^{* *}$ \\
\hline 6. & P-2-7-1A XR-138-2 & 3.29 & $52.73 * *$ & $105.0 * *$ & $129.0 * *$ & $79.08 * *$ & $10.51 * *$ & $13.1 * *$ & $17.41 * *$ & 3.69 & 3.81 & 0.86 & $106.4^{* *}$ \\
\hline 7. & P-2-7-1A XR-1-1 & 4.22 & $46.81 * *$ & $64.07 * *$ & $111.5 * *$ & $63.85 * *$ & $13.38^{* *}$ & $27.3 * *$ & $33.23 * *$ & 1.64 & 3.91 & 3.20 & $107.4^{* *}$ \\
\hline 8. & P-2-7-1A xR -107 & $6.63 *$ & $61.79 * *$ & $67.83 * *$ & $118.9 * *$ & $89.11 * *$ & $7.07 *$ & $5.4^{*}$ & $11.01 * *$ & 1.26 & 2.72 & 4.69 & $114.6^{*}$ \\
\hline 9. & P-2-7-1A XR -104 & 1.07 & $40.06 * *$ & $65.91 * *$ & $130.0 * *$ & $53.48 * *$ & $13.02 * *$ & $42.1 * *$ & $53.71 * *$ & $-5.07 *$ & 3.17 & $6.23 *$ & $117.4 * *$ \\
\hline 10 & P-89-1A XR-6D-1 & 2.49 & $63.58 * *$ & $72.41 * *$ & $112.2 * *$ & $105.99 * *$ & $11.06 * *$ & -1.2 & -3.11 & $9.33 * *$ & $8.60 *$ & 2.60 & $119.3^{* *}$ \\
\hline 11. & P-89-1A XR-12-96 & 3.50 & $76.27 * *$ & $68.06 * *$ & $109.8 * *$ & $75.17 * *$ & $5.39 *$ & $15.9 * *$ & $13.78 * *$ & $9.70 * *$ & $9.03 *$ & $5.01 *$ & $103.0^{* *}$ \\
\hline 12. & 89-1A X R-630 & 1.25 & $59.45^{* *}$ & $89.91 * *$ & $66.7 * *$ & $54.55 * *$ & -1.89 & $17.1 * *$ & $16.25 * *$ & 15.08 & $7.17 *$ & -0.58 & $48.7 * *$ \\
\hline 13. & P-89-1A XEC-601958 & $5.52 *$ & $50.50 * *$ & $67.08 * *$ & $159.0 * *$ & $149.56 * *$ & $8.81 * *$ & $9.8^{*}$ & $15.81 * *$ & -0.71 & $5.90^{*}$ & 4.06 & $168.9^{* *}$ \\
\hline 14. & P-89-1A X EC-601718 & $9.65 * *$ & $73.60 * *$ & $106.2 * *$ & $189.4 * *$ & $157.78 * *$ & 4.08 & $10.6 * *$ & $13.45^{* *}$ & 3.44 & $5.02 *$ & 1.50 & $46.0 * *$ \\
\hline 15. & P-89-1A XR-138-2 & 2.56 & $72.98 * *$ & $71.88 * *$ & $107.0 * *$ & $50.67 * *$ & 0.51 & $25.1 * *$ & $25.29 * *$ & $13.50 * *$ & $11.46^{* *}$ & 2.53 & $88.8 * *$ \\
\hline 16. & P-89-1A XR-1-1 & $\begin{array}{l}10.59 * \\
*\end{array}$ & $61.82 * *$ & $90.54 * *$ & $163.4 * *$ & $143.18 * *$ & $5.78^{*}$ & $5.3^{*}$ & $-5.33^{*}$ & $30.54 * *$ & $8.75^{*}$ & $-9.80 *$ & $125.0 * *$ \\
\hline 17. & $89-1 \mathrm{~A} \mathrm{X}$ & $6.77 *$ & $76.07 * *$ & $73.33 * *$ & $111.3 * *$ & $114.96 * *$ & $7.00 *$ & -0.4 & -2.80 & $13.86 * *$ & $6.72 *$ & 1.72 & $100.9^{* *}$ \\
\hline 18. & P-89-1A XR-104 & $9.59 *$ & $69.83 * *$ & $90.00 * *$ & $173.2 * *$ & $141.11 * *$ & $5.45^{*}$ & $11.8^{* * *}$ & $9.96 * *$ & $7.89 *$ & $9.89 *$ & $6.38^{*}$ & $157.2^{* *}$ \\
\hline 19. & CMS-10A XR-6D-1 & 2.89 & $73.54 * *$ & $87.34 * *$ & $125.8 * *$ & $167.04 * *$ & $9.12 * *$ & $-15.3 * *$ & $-19.35 * *$ & $15.78 * *$ & $7.25^{*}$ & -4.34 & $117.7 * *$ \\
\hline 20. & CMS-10A XR-12-96 & $\begin{array}{l}11.77 * \\
*\end{array}$ & $84.93 * *$ & $94.17 * *$ & $148.1 * *$ & $133.90 * *$ & 2.95 & $7.1 *$ & 3.32 & $12.94 * *$ & 3.43 & -1.93 & $123.9 * *$ \\
\hline 21. & CMS-10 A XR-630 & $7.51 *$ & $59.45 * *$ & $91.94 * *$ & $118.4 * *$ & $76.35 * *$ & 0.54 & $28.6 * *$ & $39.62 * *$ & $-7.19 *$ & $-9.13 *$ & $6.20 *$ & $107.7 * *$ \\
\hline 22. & $\begin{array}{l}\text { CMS-10A XEC- } \\
601958\end{array}$ & $\begin{array}{l}12.11 * \\
*\end{array}$ & $65.20 * *$ & $83.23 * *$ & $219.4 * *$ & $252.23 * *$ & 2.88 & 0.6 & $5.37 *$ & $10.76^{* * *}$ & 3.53 & $-6.30 *$ & $199.6 * *$ \\
\hline
\end{tabular}




\begin{tabular}{|c|c|c|c|c|c|c|c|c|c|c|c|c|c|}
\hline 23. & $\begin{array}{l}\text { CMS-10A XEC- } \\
601718\end{array}$ & $9.24 *$ & $87.26 * *$ & $120.3 * *$ & $193.0 * *$ & $179.11 * *$ & $5.20^{*}$ & $12.0 * *$ & $7.58^{*}$ & $16.66 * *$ & 3.38 & $-10.58^{*}$ & $141.9 * *$ \\
\hline 24. & CMS-10 AXR-138-2 & 3.57 & $84.01 * *$ & $101.4 * *$ & $120.7 * *$ & $53.22 * *$ & -3.14 & $36.5 * *$ & $48.40 * *$ & $-5.13 *$ & -1.88 & 2.79 & $100.2^{* *}$ \\
\hline 25. & CMS-10A XR-1-1 & 2.92 & $71.68 * *$ & $87.01 * *$ & $135.1 * *$ & $94.10 * *$ & $10.62 * *$ & $21.5 * *$ & $23.96 * *$ & 5.02 & $5.42 *$ & 3.94 & $130.6^{* * *}$ \\
\hline 26. & CMS-10A XR-107 & 4.67 & $67.43 * *$ & $76.92 * *$ & $134.9 * *$ & $103.11 * *$ & 3.42 & $13.5 * *$ & $29.82 * *$ & $\begin{array}{l}- \\
16.23 * *\end{array}$ & -3.69 & $7.02 *$ & $134.3^{* *}$ \\
\hline 27. & CMS-10 AXR-104 & 3.55 & $66.33^{* *}$ & $100.5^{* *}$ & $233.1 * *$ & $123.38 * *$ & $6.63^{*}$ & $46.7 * *$ & $36.67 * *$ & $16.96 * *$ & 3.47 & -3.59 & $182.3^{* *}$ \\
\hline 28. & CMS-107 A X R-6D-1 & $7.11 *$ & $60.06 * *$ & $68.00 * *$ & $140.6^{* *}$ & $169.53 * *$ & $7.45^{*}$ & $-8.8 *$ & -4.38 & -1.23 & -2.87 & $-7.70 *$ & $123.9 * *$ \\
\hline 29. & CMS-107A XR-12-96 & $\begin{array}{l}11.77^{*} \\
*\end{array}$ & $82.98 * *$ & $71.00 * *$ & $88.9 * *$ & $85.49 * *$ & $6.70^{*}$ & -2.3 & $-7.12 *$ & $19.37 * *$ & $8.05 *$ & $-5.18 *$ & $65.1 * *$ \\
\hline 30. & CMS-107A XR-630 & $\begin{array}{l}10.52 * \\
*\end{array}$ & $65.08 * *$ & $83.77 * *$ & $108.5^{* *}$ & $99.29 * *$ & -0.69 & -0.5 & $-5.09 *$ & $18.52 * *$ & $14.24 * *$ & 4.54 & $95.9 * *$ \\
\hline 31 & $\begin{array}{l}\text { CMS-107 AX EC- } \\
601958\end{array}$ & $7.75^{*}$ & $51.81 * *$ & $54.76^{* *}$ & $172.9 * *$ & $128.14 * *$ & $8.95^{*}$ & $17.6^{* * *}$ & $26.62 * *$ & -3.88 & $7.82 *$ & 2.22 & $178.8 * *$ \\
\hline 32 & $\begin{array}{l}\text { CMS-107A XEC- } \\
601718\end{array}$ & $6.53 *$ & $59.60 * *$ & $62.8 * *$ & $153.6^{* *}$ & $87.19 * *$ & $8.95^{*}$ & $31.8 * *$ & $41.03 * *$ & -4.16 & 3.37 & -0.14 & $136.1 * *$ \\
\hline 33 & CMS-107A xR-138-2 & $5.67 *$ & $75.94 * *$ & $68.82 * *$ & $99.9 * *$ & $71.73 * *$ & $13.02 * *$ & $14.6 * *$ & $20.08 * *$ & 1.17 & 2.24 & $5.65^{*}$ & $87.9 * *$ \\
\hline 34 & CMS-107A X R-1-1 & 2.66 & $65.95 * *$ & $72.30 * *$ & $122.6^{* *}$ & $102.43 * *$ & $7.11 *$ & $15.4 * *$ & $19.80 * *$ & 2.24 & 2.47 & -1.34 & $108.0 * *$ \\
\hline 35 & CMS-107A XR-107 & $7.45^{*}$ & $70.58 * *$ & $69.23 * *$ & $115.2^{* *}$ & $98.13 * *$ & 3.49 & $7.5^{*}$ & $10.56 * *$ & $7.13 * *$ & 1.26 & -3.60 & $93.9 * *$ \\
\hline 36 & CMS-107A X R-104 & $9.68 *$ & $70.90 * *$ & $76.84 * *$ & $126.4 * *$ & $54.84 * *$ & 3.68 & $44.7 * *$ & $67.07 * *$ & $-11.44 * *$ & $15.24 * *$ & $6.18 *$ & $117.5^{* *}$ \\
\hline & SEm ( \pm ) MD.P & 0.26 & 1.12 & 0.10 & 26.01 & 29.00 & 0.31 & $\mathbf{0 . 3 0}$ & 0.231 & 1.73 & 1.08 & 0.23 & 11.23 \\
\hline & Lowest & 1.07 & 31.46 & 54.76 & 66.7 & 53.22 & 4.18 & -15.3 & -19.35 & -16.23 & -9.13 & -10.58 & 46.9 \\
\hline & Highest & 12.11 & 87.26 & 120.3 & 233.1 & 252.23 & 13.38 & 46.7 & 67.07 & 30.54 & 15.24 & 7.02 & 199.6 \\
\hline
\end{tabular}

